\title{
Public health intervention strategies to tackle vector-borne diseases in Quebec
}

\author{
Lowe $\mathrm{AM}^{1 *}$
}

\begin{abstract}
Affiliation
${ }^{1}$ Unité surveillance, évaluation de risque et contrôle des maladies infectieuses, Direction des risques biologiques et de la santé au travail, Institut national de santé publique du Québec, Montréal, QC
\end{abstract}

*Correspondence: anne-marie.lowe@inspq.qc.ca

Suggested citation: Lowe AM. Public health intervention strategies to tackle vector-borne diseases in Quebec. Can Comm Dis Rep 2016;42:213-4. https://doi.org/10.14745/ccdr.v42i10a10

\section{Background}

Effectively decreasing vector-borne diseases (VBDs) involves understanding local vector ecology and patterns of disease transmission through surveillance and research before choosing the appropriate public health interventions.

\section{Objective}

To describe why, where and how to intervene to protect the population from VBDs in the context of urbanization and climate change, and to present different risk assessment processes and intervention strategies in Quebec.

\section{Narrative}

Vector-borne diseases require a pathogen of interest, vector(s), reservoir(s), the environment into which both the pathogen and vector evolve and animal or human hosts. The National Institute for Public Health of Quebec (Institut national de santé publique du Québec; INSPQ) has framed a public health risk management strategy that includes risk assessment that leads to intervention options for public health authorities including regional health boards and the Quebec Ministry of Health and Social Services (Ministère de la santé et des services sociaux [MSSS]) (1). The province's legislation foresees the establishment of governmental intervention plans to control VBDs when the health of the population is threatened by potentially infective vectors (2).

Governmental intervention plans were established following the discovery of West Nile virus in Quebec in 2002 (3). Integrated surveillance by INSPQ monitors human and animal cases and analyses mosquito surveillance data. The epidemiology of this infection varies in time and space, generating unpredictable outbreaks.

Intervention strategies to reduce the morbidity and mortality associated with West Nile virus include using larvicides, communicating with the public about the risk of the disease and about how to decrease exposure and reduce breeding sites, and communicating with physicians about diagnosis, treatment and reporting. Héma-Québec is following preventive measures by screening blood donations.
The public health intervention strategy regarding Lyme disease is different. This disease has a different epidemiology, progressing slowly northward from the southern border. The first case reported to be acquired in Quebec was in 2006; since then, the number of local cases has increased. The Regional Health Board in the Montérégie, one of the regions of Quebec where the risk is substantial, has been proactive in managing the risk, mainly through educating the public about preventive measures, including modifying the landscape to reduce tick-breeding sites and small-rodent reservoirs.

In 2014-2015, the MSSS intervened to limit the number of locally acquired cases of Lyme disease and to reduce complications associated with the disease. Province-wide communications were sent to outdoor enthusiasts and residents in affected areas about the risk, preventative measures (such as checking for and effectively removing ticks) and early symptoms that should be seen by a health professional. Physicians were also provided with detailed explanations about the risk of Lyme disease following a tick bite, ways to improve diagnosis and the tools available to guide post-exposure prophylaxis (4).

The Quebec population is also at risk of Zika virus infection when travelling in countries with mosquito-borne transmission, as well as locally through sexual and possibly blood-borne transmission. The epidemic that emerged in 2015 in Brazil has led to the discovery of a causal link between Zika virus infection and congenital abnormalities, including microcephaly. Travel clinics explain the risk of transmission and suitable preventive measures, as do health professionals who work with vulnerable populations, particularly pregnant women. Héma-Québec has started excluding all blood donations from people who have travelled in countries with known Zika virus transmission. INSPQ has developed a risk assessment on the emergence and transmission of Zika virus in Quebec, taking into account the major public health consequences that this infection could have on the population (5).

Climate change has impacts on VBDs, and Quebec must adapt to protect the health of its population. Ongoing challenges include supporting efficient risk assessment, ensuring available interventions are cost-effective, and being aware that adaptation strategies to some health issues (e.g. heat island effect) might conflict with VBD intervention strategies (increasing vectors habitat). 
The One Health approach looks at public health issues at the human-animal-environment interface. This approach would allow cities to adapt to VBDs in a changing climate. In Quebec, it is central to the activities and mission of the Observatory on Zoonoses and Climate Change Adaptation, created by INSPO in 2015. This interdisciplinary structure allows experts and policy makers to share knowledge, concerns and potential approaches in dealing with zoonoses, including VBDs, and climate change adaptation (6).

\section{Conclusion}

Human surveillance, vector surveillance and a shared vision are needed to develop integrated intervention strategies against VBDs. Mitigation efforts might be the key to ensure that adaptation to one public health issue does not interfere with another. The Observatory on Zoonoses and Climate Change Adaptation is an innovative way to demonstrate One Health in practice.

\section{Conflict of interest}

None.

\section{References}

1. Cortin V, Laplante L, Dionne M, Filiatrault F, Laliberté C, Lessard $\mathrm{P}$ et al. La gestion des risques en santé publique : cadre de référence. Québec (QC): INSPQ; 2016 Mar 14. https://www.inspq.qc.ca/publications/2106.

2. Gouvernement du Québec. Loi sur la santé publique. Québec (QC): Légis Québec; 2016 Apr 1. http:// legisquebec.gouv.qc.ca/fr/ShowDoc/cs/S-2.2.

3. MSSS. Plan d'intervention gouvernemental 2013-2015 pour la protection de la population contre le virus du Nil occidental. Québec (QC): MSSS; 2013 Jun 10. http:// publications.msss.gouv.qc.ca/msss/document-000135/.

4. INSPQ. La maladie de Lyme et les maladies transmises par les tiques. Carte de risque et municipalités à risque d'acquisition de la maladie de Lyme. Québec (QC): INSPQ; 2016. https://www.inspq.qc.ca/zoonoses/maladie-de-lyme.

5. INSPQ. Évaluation du risque d'émergence et de transmission vectorielle du virus Zika au Québec. Québec (QC): INSPQ; 2016 Jun 29. https://www.inspq.qc.ca/ publications/2148.

6. INSPO. Observatoire multipartite québécois sur les zoonoses et l'adaptation aux changements climatiques. Québec (QC): INSPQ; 2015 Dec 8. https://www.inspq.qc.ca/ zoonoses/observatoire.

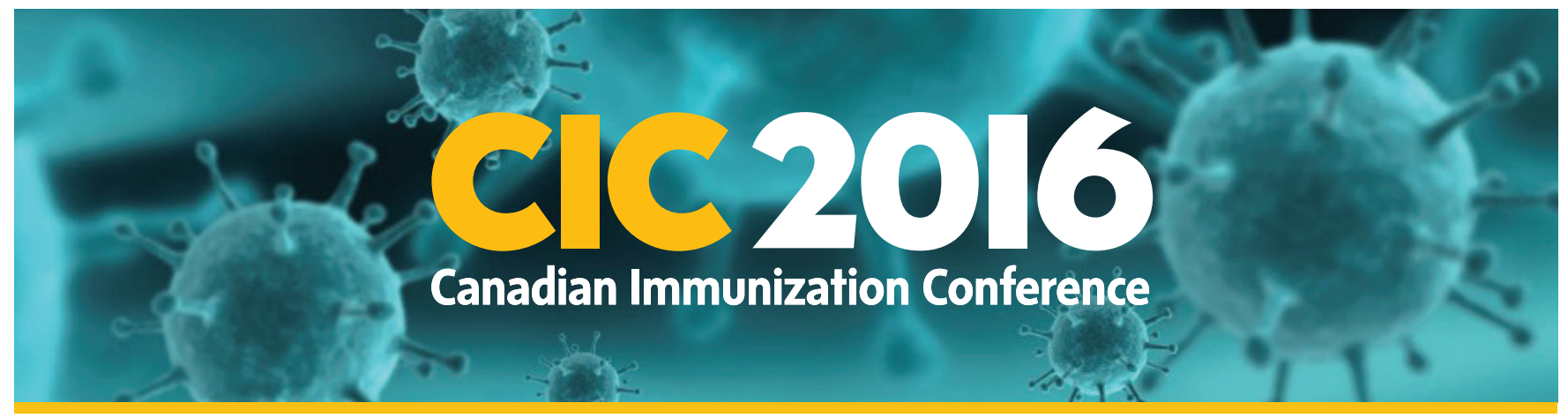

\title{
Canadian Immunization Conference 2016
}

\author{
December 6-8, 2016 | Shaw Centre \\ Ottawa, Ontario, Canada
}

Early Bird Rate available until October 11, 2016

\section{REGISTER NOW cic-cci.ca/registration}

